ISSN: 2302-8556

E-Jurnal Akuntansi Universitas Udayana

Vol.26.2.Februari (2019): 1494-1517

DOI: https://doi.org/10.24843/EJA.2019.v26.i02.p24

\title{
Pengaruh Audit Tenure, Kompleksitas Audit, Dan Time Buget Pressure Terhadap Kualitas Audit Di Kantor Akuntan Public Provinsi Bali
}

\author{
Ni Putu Nanna Chintya Dewi ${ }^{1}$ \\ Kadek Trisna Dwiyanti ${ }^{2}$
}

\author{
1,2 Fakultas Ekonomi dan Bisnis, Universitas Pendidikan Nasional (Undiknas), \\ Bali, Indonesia \\ e-mail: Nannachintya42@gmail.com
}

\begin{abstract}
ABSTRAK
Penelitian ini bertujuan untuk mengetahui pengaruh audit tenure, kompleksitas audit, dan time budget pressure terhadap kualitas audit. Penelitian ini dilakukan di Kantor Akuntan Publik Provinsi Bali yang tergabung pada IAPI (Institut Akuntan Publik Indonesia). Sebanyak 65 responden dijadikan sampel, dengan metode non probability sampling dengan menggunakan teknik purposive sampling. Pengumpulan data dilakukan melalui penyebaran kuesioner. Teknik analisis yang digunakan adalah analisis regresi linier berganda. Hasil penelitian menunjukkan bahwa, pengaruh audit tenure, kompleksitas audit, dan time budget pressure berpengaruh terhadap kualitas audit.
\end{abstract}

Kata kunci: Audit tenure; kompleksitas audit; time budget pressure; kualitas audit.

\section{ABSTRACT}

This study, which was conducted at the Bali Provincial Public Accountant Office incorporated in IAPI (Indonesian Institute of Certified Public Accountants), aims to determine the effects of audit tenure, audit complexity, and time budget pressure on audit quality. A total of 65 respondents were sampled, with a non-probability sampling method with a purposive sampling technique. The data collection was done through spreading questionnaires and the analysis technique was multiple linear regression. The result showed that the influence of audit tenure, audit complexity, and time budget pressure affected audit quality.

Keywords : audit tenure; audit complexity; time budget pressure; audit quality.

\section{PENDAHULUAN}

Pada umumnya perusahaan memiliki arah tujuan yang jelas dalam mengembangkan usahanya. Perusahaan merupakan suatu perkumpulan dua orang atau lebih yang memiliki kesamaan prinsip dan saling berinteraksi dalam menjalankan aktivitasnya untuk mencapai tujuan bersama. Suatu laporan keuangan sangatlah penting didalam perusahaan, karena dengan melihat laporan keuangan, perusahaan dapat mengetahui informasi keuangan perusahaan 
Ni Putu Nanna Cintya Dewi dan Kadek Trisna Dwiyanti. Pengaruh...

selama kurun waktu tertentu dan mengetahui kondisi perusahaan secara aktual. Laporan keuangan dibuat dan diterbitkan untuk dapat memberikan informasi keuangan bagi pihak eksternal maupun pihak internal perusahaan. Guna menghindari kesalahan yang dapat terjadi didalam perusahaan maka suatu laporan keuangan perlu di audit oleh akuntan publik karena akuntan di anggap pihak yang bersifat independen. Jika laporan keuangan belum melalui proses audit, maka laporan tersebut kewajarannya kurang dipercaya oleh pihak yang berkepentingan.

Akuntan publik memiliki kewajiban untuk menjaga dan meningkatkan kualitas auditnya agar terciptanya kepercayaan publik terhadap keakuratan dan validitas laporan keuangan auditan yang diterbitkan oleh auditor. Adanya risiko informasi yang tidak kredibel dalam laporan keuangan akan mempengaruhi kualitas audit sebab informasi tersebut akan dipertimbangkan oleh para pemangku kepentingan. Oleh sebab itu audit yang berkualitas dilakukan agar dapat menciptakan kredibilitas laporan keuangan bagi para pengguna informasi akuntansi. Kualitas audit sangat penting agar nantinya informasi dalam laporan keuangan dapat digunakan sebagai dasar pengambilan keputusan yang andal oleh stakeholders, yaitu pemegang saham, pemasok, kreditur, para pekerja, pelanggan dan pemerintah. Kualitas audit adalah kemungkinan bahwa auditor akan menemukan dan melaporkan salah saji material yang terjadi dalam laporan keuangan klien. Chadegani \& Jari (2011) mendefinisikan kualitas audit dalam hal tingkat jaminan karena tujuan audit adalah untuk memberi jaminan terhadap laporan keuangan, kualitas audit adalah probabilitas bahwa laporan keuangan tidak mengandung salah saji material. 
Kualitas auditor yang dipilih perusahaan untuk melakukan audit akan menentukan kredibilitas laporan keuangan auditan. Munawir (2008) menjelaskan bahwa standar auditing yang berlaku umum dan kode etik profesi akuntan merupakan pedoman bagi auditor yang ingin mencapai kualitas pekerjaan yang tinggi. Yuniarti (2012) mendefinisikan kualitas audit sebagai sesuatu yang abstrak sehingga sulit untuk diukur. Kualitas audit merupakan konsep yang sangat subyektif, yang tidak bisa diukur secara akurat, tetapi hanya proksi yang digunakan untuk membantu dalam penilaian konsep seperti ini. Proksi adalah alat ukur yang diperlukan dalam pengukuran variabel pada saat pengambilan data. Indikator tidak langsung atau proksi digunakan untuk mengukur perubahan atau hasil dimana pengukuran langsung tidak memungkinkan diperoleh indikatornya.

Audit tenure merupakan salah satu faktor yang mempengaruhi kualitas audit (Lee \& Sukartha, 2017). Audit tenure ialah jangka waktu perikatan yang dilaksanakan antara auditor dari suatu KAP dengan klien. Audit tenure merupakan salah satu faktor yang mempengaruhi kualitas audit (Lee \& Sukartha, 2017). Audit tenure ialah jangka waktu perikatan yang dilaksanakan antara auditor dari suatu KAP dengan klien audit yang sama (Werastuti, 2013). Audit tenure dapat mempengaruhi kualitas audit dilihat dari jangka waktu perikatan auditor dengan auditee. Pihak pemerintah sebagai regulator diharapkan dapat memfasilitasi kepentingan dari semua pihak, baik dari pihak akuntan, pihak perusahaan dan pihak eksternal. Pembatasan masa perikatan (audit tenure) merupakan usaha untuk mencegah adanya perilaku auditor terlalu dekat berinterasi dengan klien sehingga tidak mengganggu sikap independensi auditor 
Ni Putu Nanna Cintya Dewi dan Kadek Trisna Dwiyanti. Pengaruh...

dalam melaksanakan tugasnya melakukan pemeriksaan terhadap laporan keuangan klien. Oleh karena itu, diberlakukan peraturan pemerintah mengenai rotasi maupun masa perikatan (audit tenure) untuk mengurangi tanggapan masyarakat tentang adanya hubungan emosional yang terjalin antara auditor dengan klien dan dapat memulihkan kepercayaan masyarakat.

Di Indonesia, dengan adanya peraturan yang mengatur tentang audit tenure maka para akuntan publik akan dapat berkerja secara professional sehingga secara langsung akan berdampak dan mempengaruhi kualitas audit yang dihasilkan. Penelitian oleh Manry, Mock, \& Tumer (2008) menyatakan bahwa audit tenure menyebabkan peningkatan kualitas audit. Selaras dengan penelitian Myers, A., \& Omer (2003) juga menemukan bukti bahwa kualitas audit semakin meningkat ketika audit tenure semakin lama. Berdasarkan landasan teori dan hasil penelitian diatas, maka dikemukakan hipotesis sebagai berikut.

$\mathrm{H}_{1}$ : $\quad$ Audit tenure berpengaruh positif terhadap kualitas audit.

Selain audit tenure, kualitas audit juga dipengaruhi oleh faktor lain yaitu kompleksitas audit. Kompleksitas audit dapat diartikan sebagai suatu tugas rumit, sulit untuk diukur dan membingungkan secara objektif, karena perspektif masing-masing individu berbeda. Hal tersebut tergantung dari bagaimana setiap individu merespon sulitnya tugas yang diberikan. Sanusi \& Iskandar (2007) mendefinisikan kompleksitas tugas sebagai tugas yang tidak terstruktur, membingungkan dan sulit. Kompleksitas tugas dalam pengauditan dipengaruhi oleh beberapa faktor yaitu (1) banyaknya informasi yang tidak relevan dalam artian informasi tersebut tidak konsisten dengan kejadian yang akan 
diprediksikan, (2) adanya ambiguitas yang tinggi, yaitu beragamnya outcome (hasil) yang diharapkan oleh klien dari kegiatan pengauditan.

Dalam tahapan audit, auditor tidak jarang dihadapkan oleh tugas-tugas yang kompleks, berbeda namun saling terkait satu dengan yang lain. Persepsi yang tidak sama tentang tugas audit membuat banyak opini tentang pertimbangan auditor yang dilakukan oleh auditor yang berbeda-beda. Ada yang mengatakan tugas audit yang diberikan mudah, ada juga yang mengatakan tugas tersebut begitu sulit dan kompleks. Kompleksitas dapat muncul dari adanya ketidakjelasan suatu tugas dan juga struktur tugas yang lemah, baik itu dalam tugas yang bersifat utama maupun tugas lainnya. Locke \& Latham (1990) menjelaskan bahwa terdapat dua aspek penyusunan kompleksitas tugas, yaitu tingkat kesulitan tugas dan struktur tugas. Tingkat kesulitan tugas dalam konteks ini dimana auditor selalu dihadapkan dengan banyaknya informasi tentang tugas tersebut. Struktur tugas terkait dengan kejelasan informasi yang didapat oleh auditor. Seringkali auditor kesulitan dalam melakukan suatu pertimbangan dikarenakan auditor tidak tahu struktur tugas yang akan mereka lakukan.

Kompleksitas tugas juga menunjukkan tingkat inovasi dan pertimbangan audit yang diperlukan auditor dalam menyelesaikan tugas. Kompleksitas tugas yang rendah memerlukan tingkat inovasi dan pertimbangan audit yang relatif sedikit, tetapi kompleksitas tugas yang tinggi memerlukan tingkat inovasi dan pertimbangan yang tinggi (Jiambalvo \& Pratt, 1982). Jika auditor dihadapkan pada suatu tugas dengan kompleksitas yang tinggi auditor akan mengalami kesulitan dalam menyelesaikan tugas audit. Hal ini akan membuat auditor tidak 
Ni Putu Nanna Cintya Dewi dan Kadek Trisna Dwiyanti. Pengaruh...

mampu mengintegrasikan informasi menjadi suatu judgment yang baik. Hasil penelitian oleh Prasita \& Adi (2007); Suwardi (2010); Riyandari \& Badera (2017); Engko \& Gudono (2007) menyimpulkan bahwa semakin tinggi kompleksitas audit maka semakin rendah kualitas auditnya. Berdasarkan landasan teori dan hasil penelitian diatas, maka dikemukakan hipotesis sebagai berikut.

$\mathrm{H}_{2}$ : Kompleksitas audit berpengaruh negatif terhadap kualitas audit.

Selanjutnya, Jelista (2015) menyimpulkan bahwa kualitas audit juga dipengaruhi oleh time budget pressure. Time budget pressure adalah suatu keadaan yang menunjukkan auditor dituntut untuk melakukan efesiensi terhadap anggaran waktu yang telah disusun atau terdapat pembatasan waktu dalam anggaran yang sangat ketatadan kaku (Sososutiksno, 2010). Pada perencanaan audit ditetapkanlah anggaran waktu (time budget) yang disusun oleh KAP dengan disetujui oleh klien. Time budget yang tepat dapat digunakan sebagai dasar untuk memperkirakan biaya yang timbul dari proses audit. Jika waktu yang diperlukan dalam menyelesaikan tugas audit yang diberikan terlalu lama, hal ini dapat memengaruhi cost audit dan efektivitas dari pelaksanaan proses audit. Klien dapat berpindah ke KAP yang lain apabila waktu yang diperlukan dalam menyelesaikan tugas yang diberikan terlalu lama dan biaya yang dikeluarkan oleh klien tinggi. Time budget pressure waktu akan terjadi bila jumlah waktu yang dianggarkan kurang dari total waktu yang tersedia. Time budget pressure berhubungan dengan tekanan yang diterima seorang auditor 
ketika mencoba untuk meyelesaikan pekerjaan audit dalam waktu audit yang telah dianggarkan dan ditetapkan oleh perusahaan audit.

Secara umum, tekanan anggaran waktu audit yang terjadi ketika audit mengalokasikan anggaran suatu perusahaan, sejumlah angka jam audit yang akan digunakan olek auditor untuk menyelesaikan prosedur audit yang ditentukan (Marghein, 2005). Tuntutan laporan yang berkualitas dengan anggaran waktu terbatas tentu saja merupakan tekanan tersendiri bagi auditor, karena kondisi yang tertekan (secara waktu) menyebabkan auditor cenderung berperilaku disfungsional, misalnya melakukan premature sign off, terlalu percaya kepada penjelasan dan presentasi klien, serta gagal menginvestasi isu-isu relevan, yang pada alirannya dapat menghasilkan laporan audit dengan kualitas rendah (Widiarta, 2013).

Tekanan anggaran waktu telah menjadi masalah yang serius bagi auditor berkaitan dengan penugasan audit. Bahkan, beberapa auditor mengalami tekanan yang cukup besar ketika dihadapkan pada suatu penugasan audit dengan time budget yang sangat singkat dan tidak terukur. Tingkat tekanan anggaran waktu yang tinggi akan mendorong auditor untuk melakukan perulaku disfungsional (Suprianto, 2009). Secara umum, tekanan anggaran waktu audit yang terjadi ketika audit mengalokasi anggaran suatu perusahaan, sejumlah angka jam audit yang akan digunakan oleh auditor untuk menyelesaikan prosedur audit ditentukan (Marghein, 2005). Penelitian yang dilakukan oleh Prasita \& Adi (2007) menyimpulkan bahwa time budget pressure berpengaruh negatif terhadap kualitas audit, penelitian tersebut sejalan dengan penelitian yang dilakukan oleh 
Ni Putu Nanna Cintya Dewi dan Kadek Trisna Dwiyanti. Pengaruh...

Ningsih (2013); Kurnia \& Khomsiyah (2014) yang menyatakan bahwa semakin tinggi atau sempit time budget pressure yang diberikan klien kepada auditor, dapat menyebabkan menurunnya kualitas audit yang akan dihasilkan. Berdasarkan landasan teori dan hasil penelitian diatas, maka dikemukakan hipotesis sebagai berikut.

$\mathrm{H}_{3}$ : $\quad$ Time budget pressure berpengaruh negatif terhadap kualitas audit.

Pada penelitian ini, Teori atribusi digunakan guna memberikan penjelasan mengenai bagaimana cara menentukan penyebab dan motif perilaku seseorang. Teori ini diarahkan untuk mengembangkan penjelasan dari cara-cara kita menilai orang secara berlainan, tergantung makna apa yang kita hubungkan (atribusikan) kesuatu perilaku tertentu (Lestari, 2010). Robbins \& Judge (2008) mengemukakan bahwa teori ini dilakukan untuk menentukan apakah perilaku individu disebabkan secara internal atau eksternal. Model of Scientific Reasoner Febriana (2012) mendeskripsikan 4 informasi penting untuk menyimpulkan atribusi seseorang, sebagai berikut (1) Distingsi atau kekhususan (distinctiveness) yaitu bahwa perilaku dapat dibedakan dari perilaku orang lain saat menghadapi situasi yang sama. (2) Konsensus (consensus) yaitu jika orang lain setuju bahwa perilaku diatur oleh beberapa karakteristik personal. (3) Konsisten dari waktu ke waktu (consistency over time) yaitu bahwa apakah seseorang akan mengulangi perilaku yang sama. (4) Cara dimana perilaku itu dilakukan (consistency over modality) yaitu bahwa apakah seseorang mengulangi perilaku pada situasi yang berbeda. 
Selain menggunakan teori atribusi pada penelitian ini juga digunakan teori lainnya, yakni teori pengharapan. Teori pengharapan menyatakan bahwa motivasi tergantung pada dua hal yaitu seberapa kuat kita menginginkan sesuatu dan kemungkinan kita mendapatkan sesuatu (Edy Suprianto, 2009). Teori pengharapan berlandaskan pada 4 asumsi dasar yaitu (1) Perilaku ditentukan oleh kombinasi faktor-faktor didalam diri individu dan lingkungan, (2) Individuindividu membuat keputusan tentang perilaku mereka sendiri didalam organisasi. (3) Individu-individu yang berbeda memiliki tipe-tipe kebutuhan, keinginan, dan tujuan yang berbeda. (4) Individu membuat pilihan perilaku banyak alternatif perilaku, berbasis pada persepsi mereka tentang sejauh mana suatu perilaku tertentu memberikan hasil yang diharapkan. Berdasarkan uraian latar belakang masalah tersebut maka penelitian ini akan menganalisis tentang pengaruh audit tenure, kompleksitas audit, dan time budget pressure terhadap kualitas audit KAP Provinsi Bali.

\section{METODE PENELITIAN}

Penelitian ini dilakukan di KAP Provinsi Bali yang tergabung dalam IAPI (Institut Akuntan Publik Indonesia). Populasi adalah wilayah generalisasi yang terdiri atas obyek dan subyek yang mempunyai kualitas dan karakteristik tertentu yang ditetapkan oleh peneliti untuk mempelajari dan kemudian ditarik kesimpulannya (Sugiyono, 2014). Populasi dalam penelitian ini adalah seluruh auditor yang bekerja di KAP provinsi Bali. Peneliti memilih auditor sebagai populasi karena auditor langsung terjun ke lapangan dalam melakukan profesi auditnya dalam melakukan proses audit yang dapat mempengaruhi kualitas audit. 
Ni Putu Nanna Cintya Dewi dan Kadek Trisna Dwiyanti. Pengaruh...

Rincian auditor yang bekerja di KAP provinsi Bali disajikan dalam Tabel 1 berikut:

\section{Tabel 1.}

Jumlah Auditor pada Kantor Akuntan Publik di Bali

\begin{tabular}{clc}
\hline No. & \multicolumn{1}{c}{ Nama Kantor Akuntan Publik } & Jumlah Auditor (orang) \\
\hline 1. & KAP I Wayan Ramantha & 12 \\
2. & KAP Johan Malonda Mustika \& Rekan (Cab) & 10 \\
3. & KAP K. Gunarsa & 8 \\
4. & KAP Drs. Ketut Budiartha, M.Si & 6 \\
5. & KAP Drs. Sri Marno Djogokarsono \& Rekan & 16 \\
6. & KAP Drs. Wayan Sunasdyana & 6 \\
7. & KAP Drs. Ketut Muliartha R.M \& Rekan & 11 \\
8. & KAP Aryana dan Darmayasa & 2 \\
9. & KAP Budhananda Munidewi & 7 \\
Total & & 78 \\
Sumber: & Data diolah, 2018
\end{tabular}

Metode pengumpulan sampel yang digunakan pada penelitian ini menggunakan metode non probability sampling dengan teknik purposive sampling yaitu metode penentuan sampel dengan pertimbangan tertentu dimana anggota sample akan dipilih sedemikian rupa sehingga sampel tersebut dapat mewakili sifat - sifat populasi (Sugiyono, 2014). Dimana sebanyak 65 orang auditor dijadikan responden karena adanya pengembalian dan beberapa kuesioner yang dianggap gugur. Sumber dari penelitian ini di dapat secara sekunder maupun primer, pengumpulan data yang dilakukan oleh peneliti dalam penelitian ini adalah menggunakan metode kuesioner. Kuesioner yang disebarkan berupa serangkaian pernyataan tertulis mengenai pengaruh audit tenure, kompleksitas audit, dan time budget pressure pada kualitas audit Kantor Akuntan Publik di Bali. 
ISSN: 2302-8556

E-Jurnal Akuntansi Universitas Udayana

Vol.26.2.Februari (2019): 1494-1517

\section{HASIL DAN PEMBAHASAN}

Berdasarkan SK Menteri Keuangan No.43/KMK.017/1997 tertanggal 27 Januari 1997 sebagaimana diubah dengan SK Menteri Keuangan No.470/KMK.01771999 tertanggal 4 Oktober 1999, KAP adalah lembaga yang memiliki ijin dari Menteri Keuangan sebagai wadah bagi Akuntan Publik dalam menjalankan pekerjaannya. Bentuk usaha KAP yang dikenal menurut hukum di Indonesia ada dua macam, yaitu KAP dalam bentuk Usaha Sendiri dan KAP dalam bentuk Usaha Kerjasama. KAP dalam bentuk Usaha Sendiri ini menggunakan nama akuntan publik yang bersangkutan, sedangkan KAP dalam bentuk Usaha Kerjasama menggunakan nama sebanyak-banyaknya tiga nama akuntan publik yang menjadi rekan atau partner dalam KAP yang bersangkutan. Penanggungjawab KAP usaha sendiri adalah akuntan publik yang bersangkutan, sedangkan penanggungjawab KAP usaha bersama adalah dua orang atau lebih akuntan publik yang masing-masing merupakan rekan atau partner dan salah seorang bertindak sebagai rekan pimpinan.

Berdasarkan hasil dari penyebaran kuesioner kepada seluruh KAP Provinsi Bali, dua dari sepuluh KAP yang terdaftar dalam IAPI tidak bisa disebarkan kuesioner oleh peneliti. KAP tersebut, yaitu KAP Drs. Ida Bgs Djagera yang sudah tidak beroperasi dan KAP Drs. Sri Marmo Djogosarkoro yang tidak menerima penyebaran kuesioner karena memiliki tugas dan kepentingan lainnya. Sehingga didapatkan responden sebanyak 65 responden. Dari 65 responden tersebut ditemukan hasil, sebagian besar berjenis kelamin perempuan yang berjumlah 34 orang dengan persentase sebesar 52,3 persen, ini berarti bahwa 
Ni Putu Nanna Cintya Dewi dan Kadek Trisna Dwiyanti. Pengaruh...

secara keseluruhan auditor perempuan lebih banyak dikarenakan perempuan memiliki sifat kesabaran yang lebih tinggi, lebih detail, terampil dan intuisi yang lebih tajam sehingga sesuai dengan kebutuhan untuk mencapai tujuan KAP tersebut.

Berdasarkan jenjang pendidikan, sebagian besar memiliki jenjang pendidikan S1 sebanyak 27 orang dengan persentase 41,5 persen. Hal ini berarti bahwa jenjang pendidikan auditor KAP Provinsi Bali didominasi dengan jenjang pendidikan S1 dikarenakan pendidikan S1 dianggap telah memiliki kemampuan dan kompetensi yang cukup sebagai auditor sebuah KAP. Sedangkan berdasarkan lama bekerja sebagian besar telah bekerja selama 5-10 tahun dengan jumlah sebanyak 38 orang dengan persentase sebesar 58,5. Hal ini menunjukan bahwa rata-rata auditor dalam KAP Provinsi Bali mampu bertahan dan berkarya dalam kurun waktu yang cukup lama pada masing-masing KAP tempatnya bekerja.

Tabel 2.

Hasil Statistik Deskriptif

\begin{tabular}{lccccc}
\hline & N & Minimum & Maximum & Mean & Std. Deviation \\
\hline Audit Tenure & 65 & 11.00 & 25.00 & 19.6769 & 3.97299 \\
Kompleksitas Audit & 65 & 12.00 & 30.00 & 23.1846 & 5.46549 \\
Time Budget Pressure & 65 & 14.00 & 35.00 & 25.8462 & 7.22675 \\
Kualitas Audit & 65 & 12.00 & 30.00 & 22.0769 & 4.70806 \\
Valid N (listwise) & 65 & & & & \\
\hline
\end{tabular}

Sumber: Data diolah, 2018

Dari Tabel 2. Ini menunjukan hasil analisis deskriptif dimana dapat dilihat bahwa pada variabel audit tenure, diperoleh nilai minimum dari audit tenure sebesar 11,00 sedangkan nilai maksimum sebesar 25,00. Nilai rata-rata dari audit tenure sebesar 19,6769 dan standar deviasi sebesar 3,97299. Selanjutnya pada variabel kompleksitas audit, diperoleh nilai minimum dari persepsi kompleksitas audit sebesar 12,00. Sedangkan nilai maksimum sebesar 30,00. Nilai rata-rata dari 
kompleksitas audit sebesar 23,1846 dan standar deviasi sebesar 5,46549. Selanjutnya pada variabel time budget pressure diperoleh nilai minimum dari time budget pressure sebesar 14,00. Sedangkan nilai maksimum sebesar 35,00. Nilai rata-rata time budget pressure sebesar 25,8462 dan standar deviasi sebesar 7,22675. Serta pada kualitas audit diperoleh nilai minimum dari kualitas audit sebesar 12,00. Sedangkan nilai maksimum sebesar 30,00. Nilai rata-rata dari kualitas audit sebesar 22,0769 dan standar deviasi sebesar 4,70806.

Tabel 3. Hasil Uji Validitas

\begin{tabular}{|c|c|c|c|c|}
\hline No & Variabel & Item Pernyataan & $\begin{array}{c}\text { Korelasi Item } \\
\text { Total }\end{array}$ & Keterangan \\
\hline \multirow{6}{*}{1} & \multirow{6}{*}{ Kualitas Audit (Y) } & $\mathrm{Y}_{1}$ & 0.897 & Valid \\
\hline & & $\mathrm{Y}_{2}$ & 0,901 & Valid \\
\hline & & $\mathrm{Y}_{3}$ & 0,888 & Valid \\
\hline & & $\mathrm{Y}_{4}$ & 0,912 & Valid \\
\hline & & $\mathrm{Y}_{5}$ & 0,938 & Valid \\
\hline & & $\mathrm{Y}_{6}$ & 0,914 & Valid \\
\hline \multirow{5}{*}{2} & \multirow{5}{*}{ Audit Tenure $\left(\mathrm{X}_{1}\right)$} & $\mathrm{X}_{1.1}$ & 0,928 & Valid \\
\hline & & $\mathrm{X}_{1.2}$ & 0,900 & Valid \\
\hline & & $\mathrm{X}_{1.3}$ & 0,897 & Valid \\
\hline & & $\mathrm{X}_{1.4}$ & 0,884 & Valid \\
\hline & & $\mathrm{X}_{1.5}$ & 0,917 & Valid \\
\hline \multirow{6}{*}{3} & \multirow{6}{*}{ Kompleksitas Audit $\left(\mathrm{X}_{2}\right)$} & $\mathrm{X}_{2.1}$ & 0,927 & Valid \\
\hline & & $\mathrm{X}_{2.2}$ & 0,936 & Valid \\
\hline & & $\mathrm{X}_{2.3}$ & 0,883 & Valid \\
\hline & & $\mathrm{X}_{2.4}$ & 0,933 & Valid \\
\hline & & $\mathrm{X}_{2.5}$ & 0,889 & Valid \\
\hline & & $\mathrm{X}_{2.6}$ & 0,918 & Valid \\
\hline \multirow{7}{*}{4} & \multirow{7}{*}{$\begin{array}{l}\text { Time Budget Pressure } \\
\qquad\left(\mathrm{X}_{3}\right)\end{array}$} & $\mathrm{X}_{3.1}$ & 0,934 & Valid \\
\hline & & $\mathrm{X}_{3.2}$ & 0,926 & Valid \\
\hline & & $\mathrm{X}_{3.3}$ & 0,941 & Valid \\
\hline & & $\mathrm{X}_{3.4}$ & 0,923 & Valid \\
\hline & & $\mathrm{X}_{3.5}$ & 0,926 & Valid \\
\hline & & $\mathrm{X}_{3.6}$ & 0,936 & Valid \\
\hline & & $\mathrm{X}_{3.7}$ & 0,936 & Valid \\
\hline
\end{tabular}

Sumber : Data diolah, 2018

Hasil uji validitas pada Tabel 3. menunjukan bahwa bahwa butir-butir pernyataan dalam instrumen penelitian tersebut valid karema semua variabel memiliki nilai koefisien korelasi lebih besar dari 0,30. 
Tabel 4.

Hasil Uji Reliabilitas

\begin{tabular}{clcc}
\hline No & \multicolumn{1}{c}{ Variabel } & Cronbach's Alpha & Keterangan \\
\hline 1 & Kualitas Audit $(\mathrm{Y})$ & 0,765 & Reliabel \\
2 & Audit Tenure $\left(\mathrm{X}_{1}\right)$ & 0,945 & Reliabel \\
3 & Kompleksitas Audit $\left(\mathrm{X}_{2}\right)$ & 0,960 & Reliabel \\
4 & Time Budget Pressure $\left(\mathrm{X}_{3}\right)$ & 0,975 & Reliabel \\
\hline \multicolumn{2}{l}{ Sumber : Data diolah, 2018} & &
\end{tabular}

Hasil uji reliabilitas yang disajikan pada Tabel 4. menunjukan bahwa setiap variabel memiliki nilai koefisien Alpha Cronbach lebih dari 0,60. Hal ini dapat dikatakan bahwa variabel kualitas audit, audit tenure, kompleksitas audit, dan time budget pressure reliabel.

Uji normalitas dilakukan untuk menguji apakah pada residual dari model regresi yang telah dibuat berdistribusi normal atau tidak. Untuk menguji normalitas residual digunakan uji statistik non-parametrik Kolmogorov-Smirnovi $(K-S)$.

Tabel 5.

Hasil Uji Normalitas

\begin{tabular}{lcc}
\hline & Statistik & Df \\
\hline Unstandardized Residual & 0.158 & 65 \\
\hline
\end{tabular}

Sumber : Data diolah, 2018

Berdasarkan Tabel 5. dapat dilihat bahwa nilai signifikan adalah sebesar 0,158. Hasil tersebut mengandung bahwa model persamaan regresi berdistribusi normal karena nilai signifikan sebesar 0,185 lebih besar dari nilai alpha 0,05.

Uji Multikolinearitas bertujuan untuk menguji apakah ditemukan adanya korelasi antar variabel bebas. Adanya multikolinieritas dapat dilihat dari nilai toleranc atau variance inflation factor $(V I F)$. Jika nilai tolerance lebih dari 0,10 atau sama dengan nilai $V I F<10$. Maka dikatakan tidak terjadi multikolinearitas. 
Tabel 6.

Hasil Uji Multikolinearitas

\begin{tabular}{lcc}
\hline \multicolumn{1}{c}{ Variabel } & Tolerance & VIF \\
\hline Audit Tenure & 0,956 & 1,046 \\
Kompleksitas Audit & 0,446 & 2,243 \\
Time Budget Pressure & 0,459 & 2,177 \\
\hline Sumber : Data diolah, 2018 & &
\end{tabular}

Berdasarkan Tabel 6. dapat diatas dilihat bahwa dari nilai tolerance dan variance inflation factor (VIF) dari variabel audit tenure, kompleksitas audit, dan time budget pressure. Nilai tersebut menunjukan bahwa nilai tolerance untuk setiap variabel lebih dari 0,10 dan nilai variance inflation factor (VIF) lebih kecil dari 10 yang berarti model persamaan regresi bebas dari multikolinearitas.

Uji Heterokedastisitas digunakan untuk mengetahui ada tidaknya ketidaksamaan varian dari residual pada modela regresi. Cara untuk mendeteksi ada tidaknya heterokedastisitas dapat diketahui dengan menggunakan uji statistik Glejser. Model dikatakan tidak mengandung gejala heterokedastisitas jika tabel coefficients menghasilkan nilai signifikansi lebih besar dari alpha 0,05.

Tabel 7.

Hasil Uji Heterokedastisitas

\begin{tabular}{lccccc}
\hline \multirow{2}{*}{ Model } & \multicolumn{2}{c}{$\begin{array}{c}\text { Unstandardized } \\
\text { Coefficients }\end{array}$} & $\begin{array}{c}\text { Standardized } \\
\text { Coefficients }\end{array}$ & \multirow{2}{*}{ T } & Sig. \\
\cline { 2 - 4 } & $\mathbf{B}$ & Std. Error & Beta & & \\
\hline (Constant) & 3.982 & 1.692 & & 2.353 & .022 \\
Audit Tenure & -.063 & 0.059 & -.137 & -1.060 & .293 \\
Kompleksitas Audit & .013 & 0.063 & .040 & .213 & .832 \\
Time Budget Pressure & -.009 & 0.047 & -.035 & -.187 & .852 \\
\hline Sumber $:$ Data diolah, 2018 & & & & &
\end{tabular}

Pada Tabel 7. dapat dilihat bahwa nilai signifikansi dari variabel audit tenure adalah sebesar 0,293, Komplesitas audit sebesar 0,832, dan 
Ni Putu Nanna Cintya Dewi dan Kadek Trisna Dwiyanti. Pengaruh...

time budget pressure sebesar 0,852 . Seluruh nilai masing-masing variabel tersebut lebih besar dari alpha 0,05 yang berarti bahwa model yang dibuat tidak mengandung gejala heterokedastisitas.

Analisis yang digunakan pada penelitian ini adalah analisis regresi linear berganda serta analisis determinasi, analisis regresi linear berganda bertujuan untuk mengetahui ketergantungan suatu variabel terikat dengan satu atau lebih variabel bebas. Analisis ini juga dapat menduga arah dari hubungan tersebut serta mengukur derajat keeratan hubungan antara satu variabel terikat dengan satu variabel bebas. Adapun hasil analisis regresi dengan menggunakan program SPSS dapat dilihat pada Tabel 8.

Tabel 8.

Hasil Analisis Regresi Linear Berganda

\begin{tabular}{|c|c|c|c|}
\hline Variabel terikat & Variabel Bebas & Koefisien Regresi & Sig. \\
\hline \multirow[t]{3}{*}{ Kualitas Audit } & Audit Tenure & 0,399 & 0,001 \\
\hline & Kompleksitas Audit & $-0,252$ & 0,037 \\
\hline & Time Budget Pressure & $-0,198$ & 0,029 \\
\hline Constant & $=25,203$ & F Ratio $=19,801$ & \\
\hline 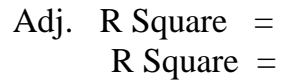 & $\begin{array}{l}0,459 \\
0,484\end{array}$ & Sig. $=0,000^{b}$ & \\
\hline
\end{tabular}

Sumber : Data diolah, 2018

Berdasarkan Tabel 8. dapat ditulis persamaan regresi linear berganda sebagai berikut.

$$
\mathrm{Y}=\mathrm{a}+\mathrm{b}_{1} \cdot \mathrm{X}_{1}+\mathrm{b}_{2} \cdot \mathrm{X}_{2}+\mathrm{b}_{3} \cdot \mathrm{X}_{3}+\mathrm{e}
$$

Keterangan:

$\begin{aligned} \mathrm{a} & =\text { Konstanta } \\ \mathrm{b}_{1}, \mathrm{~b}_{2}, \mathrm{~b}_{3}= & \text { Koefisien Garis Regresi } \\ \mathrm{Y} & =\text { Variabel Terikat (Kualitas Audit) } \\ \mathrm{X}_{1}, \mathrm{X}_{2}, \mathrm{X}_{3}= & \quad \text { Variabel Bebas (Audit Tenure, Kompleksitas Audit, } \\ & \text { dan Time Budget Pressure) } \\ \mathrm{e} & \text { Error / Variabel Pengganggu }\end{aligned}$


Dilihat dari hasil statistik pada Tabel 8. pada nilai dari adjusted $\mathrm{R}^{2}$, di dapatkan hasil bahwa besar pengaruh variabel audit tenure, komplekitas audit dan time budget pressure pada kualitas audit yakni 0,484. Hal ini menunjukkan bahwa 48,4\% kualitas audit dipengaruhi oleh audit tenure $\left(\mathrm{X}_{1}\right)$, kompleksitas audit $\left(\mathrm{X}_{2}\right)$ dan time budget pressure $\left(\mathrm{X}_{3}\right)$. Sisanya, yakni sebesar $51,6 \%$ dipengaruhi oleh faktor lainnya selain audit tenure, komplekitas audit dan time budget pressure. Serta berdasarkan pada Tabel 8. disimpulkan hasil sebagai berikut.

Berdasarkan hasil uji statistik diatas terbukti bahwa $\mathrm{H}_{1}$ terdukung, dengan melihat perbandingan antara besar nilai signifikansi t hitung variabel audit tenure dengan nilai sig $0,001<\alpha(0,05)$. Hal ini memiliki arti bahwa audit tenure berpengaruh positif dan signifikan terhadap kualitas audit, dimana semakin lama masa perikatan audit maka akan dapat meningkatkan kualitas audit.

Hasil penelitian ini selaras dengan hasil penelitian yang dilakukan oleh Nuratama (2011) yang menyatakan lamanya masa perikatan audit akan berpengaruh positif signifikan terhadap kualitas audit, serta hasil penelitian Lee \& Sukartha (2017) yang menyimpulkan bahwa audit tenure berpengaruh terhadap kualitas audit, pada penelitian tersebut dapat dikatakan bahwa auditor yang ditunjuk oleh manajemen secara terus menerus atau secara berkelanjutan akan lebih memahami kompleksitas perusahaan karena auditor sudah mengetahui sistem pengendalian internal auditee sehingga masa perikatan atau audit tenure berpengaruh positif pada kualitas audit. Audit tenure yang panjang akan memberikan hasil kualitas audit yang lebih baik. 
Ni Putu Nanna Cintya Dewi dan Kadek Trisna Dwiyanti. Pengaruh...

Sejalan dengan penelitian yang dilakukan oleh Premananda \& Badera (2016) yang menyatakan bahwa audit tenure berpengaruh positif terhadap kualitas audit. Dari hasil penelitian tersebut dapat disimpulkan bahwa semakin tinggi audit tenure maka semakin meningkat pula kualitas audit yang berarti bahwa semakin lama auditor mengadakan perikatan audit kepada kliennya menyebabkan kualitas auditnya menjadi semakin baik. Hal ini disebabkan oleh semakin lamanya masa perikatan menyebabkan auditor akan memiliki pengetahuan dan pengalaman untuk merancang prosedur audit yang efektif.

Selanjutnya, berdasarkan hasil uji statistik diatas terbukti bahwa $\mathrm{H}_{2}$ terdukung, dengan melihat perbandingan antara besar nilai signifikansi t hitung variabel kompleksitas audit dengan nilai sig $0,037<\alpha(0,05)$. Hal ini memiliki arti bahwa kompleksitas audit berpengaruh negatif dan signifikan terhadap kualitas audit, dimana semakin tinggi kompleksitas audit maka semakin rendah kualitas audit.

Hasil penelitian ini dapat mendukung hasil penelitian yang dilakukan oleh Nirmala (2013) turut menunjukkan bahwa kompleksitas audit berpengaruh negatif terhadap kualitas audit; Riyandari \& Badera (2017) menyimpulkan bahwa kompleksitas audit berpengaruh negatif pada kualitas audit, penelitian tersebut menjelaskan bahwa jika terjadi peningkatan dalam kompleksitas suatu tugas audit yang dikerjakan oleh auditor maka dapat mengakibatkan menurunnya tingkat keberhasilan auditor dalam mendeteksi segala kecurangan yang mungkin akan terjadi. Sehingga hal tersebut akan berdampak pada proses pemeriksanaan serta mengakibatkan terjadinya penurunan kualitas audit yang dihasilkan. 
Hipotesis ketiga dalam penelitian ini menduga bahwa time budget pressure berpengaruh negatif terhadap kualitas audit. Berdasarkan hasil uji statistik diatas terbukti bahwa $\mathrm{H}_{3}$ terdukung, dengan melihat perbandingan antara besar nilai signifikansi t hitung variabel time budget pressure dengan nilai sig $0,029<\alpha(0,05)$. Hal ini memiliki arti bahwa time budget pressure berpengaruh negatif dan signifikan terhadap kualitas audit, dimana semakin tinggi time budget pressure maka semakin rendah kualitas audit.

Hasil penelitian ini sejalan dengan hasil penelitian yang dilakukan oleh Savitri \& Dwirandra (2018) yang juga menyimpulkan bahwa time budget pressure berpengaruh negatif pada kualitas audit. Serta pada penelitian yang dilakukan oleh Riyandari \& Badera (2017) yang menyimpulkan bahwa time budget pressure berpengaruh negatif pada kualitas audit, penelitian tersebut memberikan hasil bahwa indikasi dengan adanya tekanan akibat terbatasnya waktu yang telah ditetapkan, dapat menimbulkan stres yang nantinya akan mendorong seorang auditor melakukan tindakan pelanggaran terhadap standar audit yang berlaku di Indonesia sekaligus dapat mendorong seorang auditor berperilaku tidak sesuai atau disfungsional, yang secara langsung berdampak rendahnya kualitas audit yang akan dihasilkan.

\section{SIMPULAN}

Berdasarkan hasil analisis dan pembahasan tentang pengaruh audit tenure, kompleksitas audit dan time budget pressure terhadap kualitas audit di KAP. Provinsi Bali, maka dapat ditarik kesimpulan bahwa audit tenure memiliki 
Ni Putu Nanna Cintya Dewi dan Kadek Trisna Dwiyanti. Pengaruh...

pengaruh positif dan signifikan terhadap kualitas audit di KAP Provinsi Bali. Hal ini berarti semakin lama masa perikatan audit maka akan dapat meningkatkan kualitas audit.

Sedangkan pada kompleksitas audit variabel ini memiliki pengaruh negatif dan signifikan terhadap kualitas audit di KAP Provinsi Bali. Hal ini berarti semakin tinggi kompleksitas audit maka semakin rendah kualitas audit. Serta pada variabel time budget pressure juga memiliki pengaruh negatif dan signifikan terhadap kualitas audit di KAP Provinsi Bali. Semakin tinggi time budget pressure maka semakin rendah kualitas audit.

Berdasarkan hasil penelitian dan kesimpulan, maka saran secara praktis yang dapat dikemukakan ialah sebaiknya Kantor Akuntan Publik memperhatikan audit tenure, kompleksitas audit, dan time budget pressure untuk dapat meningkatkan kualitas audit. Oleh karena penelitian ini hanya sebatas meneliti mengenai audit tenure, kompleksitas audit, dan time budget pressure terhadap kualitas audit. Maka selanjutnya peneliti disarankan untuk menambah variabel lain, seperti: independensi, kompentensi auditor dan ukuran Kantor Akuntan Publik. Peneliti selanjutnya juga diharapkan untuk dapat menggunakan alat analisis lainnya, serta mengambil sampel di Kantor Akuntan Publik diluar Provinsi Bali.

\section{REFRENSI}

Chadegani, A. A., M.M, Z., \& Jari, A. (2011). The Determinant Factors of Auditor Switch among Companies Listed on Tehran Stock Exchange. International Research Journal of Finance and Economics, Vol 6, pp: 34-67. 
Engko, C., \& Gudono. (2007). pengaruh kompleksitas tugas dan locus of control terhadap hubungan antara gaya kepemimpinan dan kepuasan kerja auditor. E-Jurnal Universitas Udayana, Vol 4, hal: 21-24.

Febriana, V. (2012). Faktor-faktor yang Mempengaruhi Pergantian Kantor Akuntan Publik di Perusahaan Go Publik yang Terdaftar di BEI. Jurnal Fakultas Ekonomika Dan Bisnis Universitas Diponegoro, Vol 5, hal: 15-17.

Gea, Fabian dan Wihiyani, Ni Luh Sari. (2018). Etika Auditor Sebagai Pemoderasi Pengaruh Kompetensi dan Tekanan Anggaran Waktu Terhadap Kualitas Audit. E-Jurnal Akuntansi Universitas Udayana, Vol 4, hal: 23-56.

Ghozali, Imam. (2016). Aplikasi Analisis Multivariate dengan Prograsm IBM SPSS 21. Semarang: Universitas Diponegoro.

Giri, Efraim Ferdinan. (2010). Pengaruh Tenur Kantor Akuntan Publik (KAP) dan Reputasi KAP Terhadap Kualitas Audit: Kasus Rotasi Wajib Auditor di Indonesia. Simposium Nasional Akuntansi XII Purwokerto 2010.

Hartadi, Bambang. (2012). Pengaruh Fee Audit, Rotasi KAP, dan Reputasi Auditor Terhadap Kualitas Audit di Bursa Efek Indonesia. Jurnal Ekonomi dan Keuangan, Vol 16 (1), hal: 84-103.

Hutabarat, Goodman. (2012). Pengaruh Pengalaman Time Budget Pressure dan Etika Auditor Terhadap Kualitas Audit. Jurnal Ilmiah ESAY, Vol 6 (1), hal:10-13.

Indriantoro, Nur dan Supomo. (2014). Metodologi Penelitian Bisnis untuk Akuntansi \& Manajemen. Yogyakarta: BPFE.

Jelista, M. (2015). pengaruh kompleksitas audit, tekanan anggaran waktu, dan pengalaman auditor terhadap kualitas audit dengan variabel moderating sistem informasi.

Jiambalvo, J., \& Pratt, J. (1982). Task Complexity and Leadership Effectivenes in CPA Firms. Journal Accounting and Economic, Vol 17 (1), pp: 5-18.

Kuncoro, Mudrajad. (2009). Metode Riset untuk Bisnis \& Ekonomi. Edisi Ketiga, Erlangga. Jakarta.

Kurnia, W., \& Khomsiyah, S. (2014). Pengaruh Kompetensi, Independensi, Tekanan Waktu, dan Etika Auditor Terhadap Kualitas Audit. Jurnal Akuntansi Universitas Trisakti, Vol 4 (2), hal: 12-17.

Lee, D., \& Surakartha, I Made. (2017). fee audit sebagai pemoderasi pengaruh auditor switching dan audit tenure terhadap kualitas audit. E-Journal 
Ni Putu Nanna Cintya Dewi dan Kadek Trisna Dwiyanti. Pengaruh...

Akuntansi Universitas Udayana, Vol 18 (2), hal: 56-79.

Lestari, P. A. (2010). Faktor-faktor yang Mempengaruhi Perilaku Auditor dalam Penghentian Prematur Prosedur Audit. Jurnal Akuntansi Universitas Diponegoro, Vol 9 (1), hal: 67-82.

Locke, E. A., \& Latham, G. P. (1990). A Theory of Goal Setting \& Task Performance. Prentice Hall, Englewood Cliffs, New Jersey.

Luthans. (1998). Organizational Behavior. Journal of Organizational Behavior, Vol 1 (1), pp: 123-156.

Manry, D. L., Mock, T. J., \& Tumer, J. L. (2008). does increased audit partner tenure reduce audit quality. Journal of Accounting, Auditing \& Finance, Vol 7 (2), pp: 24-36.

Marghein, L. (2005). An Empirical Analysis Of The Effects Of Auditor Time Budget Pressure and Time Deadline Presssure. The Journal of Applied Business Reaserch, Vol 7(1), PP:45-78.

Marsellia. (2012). Pengaruh Kompetensi dan Independensi Terhadap Kualitas Audit dengan Etika Auditor Sebagai Variabel Moderator (Studi Empiris pada Auditor di KAP Big Four Jakarta). Institut Bisnis dan Informatika Indonesia (IBII).

Menteri Keuangan. (2008). Peraturan Menteri Keuangan Republik Indonesia Nomor 17/PMK.01/2008 pasal 3 tentang Jasa Akuntan Publik. Jakarta.

Muliawan, Eko Kurnia dan Sujana, I Ketut. (2017). Pengaruh Ukuran Kantor Akuntan Publik, Auditor Switching Dan Audit Tenure Pada Kualitas Audit. E-Jurnal Akuntansi Universitas Udayana, Vol 16(2), hal: 11-17.

Munawir. (2008). Auditing Modern. Yogyakarta: Dosen Fakultas Ekonomika Universitas Gadjah Mada Yogyakarta.

Myers, James N., A., L., \& Omer, Thomas C. (2003). Exploring The Term Of The Auditor Client Relationship And The Quality Of Earnings: A Case For Mandatory Auditor Retation. The Accounting Review, Vol 2(1), pp: 9-21.

Ningsih, A. A. P. R. C. (2013). Pengaruh Kompetensi, Independensi, dan Time Budget Pressure Terhadap Kualitas Audit. Jurnal Akuntansi Universitas Udayana, Vol 12(2), hal 67-89.

Nirmala, P. A. (2013). Pengaruh Independensi, Pengalaman, Due Professional Care, Akuntabilitas, Kompleksitas Audit, dan Time Budget Pressure 
terhadap Kualitas Audit. Jurnal Akuntansi Universitas Diponegoro, Vol 12(1), hal: 7-9.

Nuratama, I Putu. (2011). Pengaruh Tenure dan Reputasi Kantor Akuntan Publik pada Kualitas Audit dengan Komite sebagai Variabel Moderasi. E-Jurnal Akuntansi Universitas Udayana, Vol 10(1), hal: 23-36.

Palmrose, Z. (1988). An Analysis of Auditor Ligitation and Audit Service Quality. The Accounting Review, Vol 2 (1), pp: 78-90.

Payamta. (2006). Pengaruh Kualitas Auditor, Independensi, dan Opini Audit terhadap Kualitas Laporan Keuangan. Jurnal Bisnis dan Manajemen, Vol 6(1), hal: 81-96.

Pramaswaradana, I. G. N. Indra dan Astika I. B. P. (2017). Pengaruh Audit Tenure, Audit Fee, Rotasi Auditor, Spesialsiasi Auditor, Dan Umur Publikasi Pada Kualitas Audit. E-Jurnal Akuntansi Universitas Udayana, Vol 16(1), hal: 12-32.

Prasita, A., \& Adi, priyo hari. (2007). Pengaruh Kompleksitas Audit Dan Tekanan Anggaran Waktu Terhadap Kualitas Audit Dengan Moderasi Pemahaman Terhadap Sistem Informasi. Jurnal Ekonomi Dan Bisnis, Vol 6(2), hal: 61-96.

Premananda, Wayan Hari, \& Badera, I Dewa Nyoman. (2018). Independensi Auditor Sebagai Pemediasi Pengaruh Audit Fee dan Audit Tenure pada Kualitas Audit. Jurnal Akuntansi Universitas Udayana, 17(2), hal: 53-76.

Ratha, I Made Dwi Kresna. (2015). Pengaruh Due Professional Care, Akuntabilitas, Kompleksitas Audit dan Time Budget Pressure Terhadap Kualitas Audit, E-Jurnal Akutansi Universitas Udayana, 14(2), hal: 34-45.

Riyandari, P. K., \& Badera, I. D. N. (2017). Pengalaman Auditor Sebagai Pemoderasi Pengaruh Time Budget Pressure Dan Kompleksitas Audit Pada Kualitas Audit. E-Jurnal Akuntansi Universitas Udayana, Vol 16(2), hal: 195-222.

Robbins, \& Judge. (2008). Perilaku Organisasi Buku 2.

Salsabila, dan Hepi Prayudiawan. (2011). Pengaruh Akuntabilitas, Pengetahuan Audit Dan Gender Terhadap Kualitas Hasil Kerja Auditor Internal (Studi Empiris Pada Inspektorat Wilayah Provinsi DKI Jakarta). Jurnal Telaah \& Riset Akuntans, Vol.4(1), hal: 155-177.

Sanusi, Z. M., \& Iskandar, M. T. (2007). Effects Of Goal Orientation And Task Complexity On Audit Jugment Performance. Malaysian Accounting Review, 
Vol 6(1), pp: 125-134.

Savitri, P. D. I., \& Dwirandra, A. A. N. B. (2018). Time Budget Pressure Sebagai Pemoderasi Pengaruh Due Professional Care dan Pengalaman Audit pada Kualitas Audit. Jurnal Akuntansi Universitas Udayana, Vol.17(2), hal: 135177.

Sinason, David H et. al. (2001). An Investigation of Auditor and Client Tenure. American Journal of Business, Vol 16(02), hal: 31-40.

Siregar, Sylvia Veronica, Fitriany, Arie Wibowo, dan Viska Anggraita. (2011). Rotasi dan Kualitas Audit: Evaluasi Atas Kebijakan Menteri Keuangan KMK No. 423/KMK.6/2002 Tentang Jasa Akuntan Publik.

Sososutiksno, C. (2010). perilaku disfungsional akibat tekanan anggaran waktu (studi empiris di lingkungan Badan Pengawasan Daerah Tingkat I dan Tingkat II Provinsi Maluku). Jurnal Maksi, Vol 9(2), hal: 31-40.

Sugiyono. (2014). Metode Penelitian Pendidikan Pendekatan Kuantitatif, Kualitatif dan $R \& D$.

Suprianto, E. (2009). Pengaruh Time Budget Pressure Terhadap Perilaku Disfungsional Auditor. JAI, Vol 8(2), hal: 61-100.

Suwardi, B. B. (2010). Pengaruh Tekanan Anggaran Waktu dan Kompleksitas Audit Terhadap Kualitas Audit (Studi Empiris pada Kantor Akuntan Publik). Jurnal Akuntansi Universitas Atma Jaya Yogyakarta, Vol 9(2), hal: 31-40.

Werastuti, Desak Nyoman Sri. (2013). Pengaruh Auditor Client Tenure, Debt Default, Reputasi Auditor, Ukuran Klien Dan Kondisi Keuangan Terhadap Kualitas Audit Melalui Opini Audit Going Concern. Jurnal Riset Akuntansi, Vol 12(3), hal: 37-40.

Widiarta. (2013). Pengaruh Gender, Umur dan Kompleksitas Tugas Auditor Pada Kualitas Audit Kantor Akuntan Publik di Bali. Jurnal Akuntansi Universitas Udayana, Vol 12(2), hal: 81-90.

Wiguna, Metta Yustia dan Badera I dewa Nyoman. 2016. Auditor Switching Memoderasi Pengaruh Audit Tenure Pada Kualitas Audit. E-Jurnal Akuntansi Universitas Udayana, Vol 15(2), hal: 31-44.

Yuniarti, R. (2012). The Effect of Tenure Audit and Dysfuntional Behavior on Audit Quality. International Conference on Economics, Business and Marketing Managemen IPEDR, IACSIT Press, Singapore, Vol.29, pp: 145167. 